\title{
Pb Distribution and Sources in Jiaozhou Bay, East China*
}

\author{
Dongfang Yang ${ }^{1,2,3}$, Junhui Guo ${ }^{1}$, Yinjiang Zhang ${ }^{1}$, Ziru Ding ${ }^{3}$, Zhiguo Bu ${ }^{2}$ \\ ${ }^{1}$ College of Life Science, Shanghai Ocean University, Shanghai, China \\ ${ }^{2}$ North China Sea Environmental Monitoring Center, Shanghai Ocean University, Qingdao, China \\ ${ }^{3}$ Zhoushan Sea Environmental forestating Monitoring Center, Zhoushan, China \\ E-mail: Andrew.higgins@csiro.au,Leonie.pearson@csiro.au,Luis.laredo@csiro.au \\ Received October 15, 2010; revised November 26, 2010; accepted December 29, 2010
}

\begin{abstract}
We studied the distribution, seasonal change, translocation, and source of heavy metal $\mathrm{Pb}$ based on the surface and bottom water sampling in Jiaozhou Bay in 1980 in order to know the condition of Pb before the industrial and agricultural development and to probe the distribution and translocation process of $\mathrm{Pb}$. The results show that the range of $\mathrm{Pb}$ content in the surface in the whole bay was $0.07-2.71 \mu \mathrm{g} / \mathrm{L}$, being below Grade II of the China's national water quality benchmark $(5.00 \mu \mathrm{g} / \mathrm{L})$. No Pb pollution was detected in the inner bay, while in the outer bay and the mouth, light $\mathrm{Pb}$ pollution. The $\mathrm{Pb}$ pollution in the bay waters was area sources. Horizontal and vertical distribution, and seasonal change indicated the translocation of $\mathrm{Pb}$ in the waters. $\mathrm{Pb}$ entered the water body at marine surface and sank at the marine bottom. Understanding the variable process of $\mathrm{Pb}$ in the bay provided the scientific clues for controlling $\mathrm{Pb}$ pollution from the human activities.
\end{abstract}

Keywords: Heavy Metal Pb, Distribution, Seasonal Change, Pollution Source, Jiaozhou Bay

\section{Introduction}

$\mathrm{Pb}$ can transfer in seawater, sediment, solid suspension particles, and marine bio-materials. Generally, $\mathrm{Pb}$ flowing into seawater will be adsorbed by suspension materials and subsides to the bottom of sea. In recent years, some progresses in research into heavy metal $\mathrm{Pb}$ in the bay has been [1-3].

Fast development in China resulted in growing pressures. Jiaozhou Bay as a bay in the East China in the Yellow Sea, it witnesses fast-developing industry and aquaculture. With economic development also comes pollution, especially the pollution of heavy metal. Based on the data in 1980, this paper reports $\mathrm{Pb}$ pollution source and translocation process.

Jiaozhou Bay is located in the middle of the Yellow Sea and the southern side of Shandong Peninsula, between $120^{\circ} 04^{\prime}$ and $120^{\circ} 23^{\prime} \mathrm{E}$, and $35^{\circ} 58^{\prime}$ and $36^{\circ} 18^{\prime} \mathrm{N}$, $27.8 \mathrm{~km}$ wide east to west, and $33.3 \mathrm{~km}$ long south to north. A 3-km wide mouth opens southeastward. Therefore, it is a partially closed bay. Main contributing rivers

\footnotetext{
*Funded by Key Laboratory of Marine Spill Ooil Identifcation and Damage Assessment Technology, SOA, the Director's Foundation of the Beihai Monitoring Center, the State Oceanic Administration; and a Project of Chinese Academy of Science (KZCX 2-207).
}

are Haibo, Licun, Baisha, Dagu, Yanghe and Loushan rivers, all seasonal ones in hydrological features [4-5]. In the west and north area to Jiaozhou Bay are Jimo Basin and Jiaolai Plain, the main agriculture areas.

\section{Material and Method}

The data used here were recorded in June, July, September and October in 1980 by the North China Sea Environmental Monitoring Center, SOA, in nine stations: H34, $\mathrm{H} 35$, H36, H37, H38, H39, H40, H41, and H82 (Figure 1). Four zones of A, B, C and D were added in October; totally 30 stations were added. Eight stations in Zone A: A1-A8; five in Zone B: B1-B5; eight in zone C: C1-C8; and nine stations in Zone D: D1-D9. Water samples were put into plastic bottles, and frozen at $0^{\circ} \mathrm{C}$ for measurement in laboratory with flameless atomic absorption spectrometric method [6].

\section{Results}

\subsection{Amount of Content}

In June, July, September and October in 1980, in the 


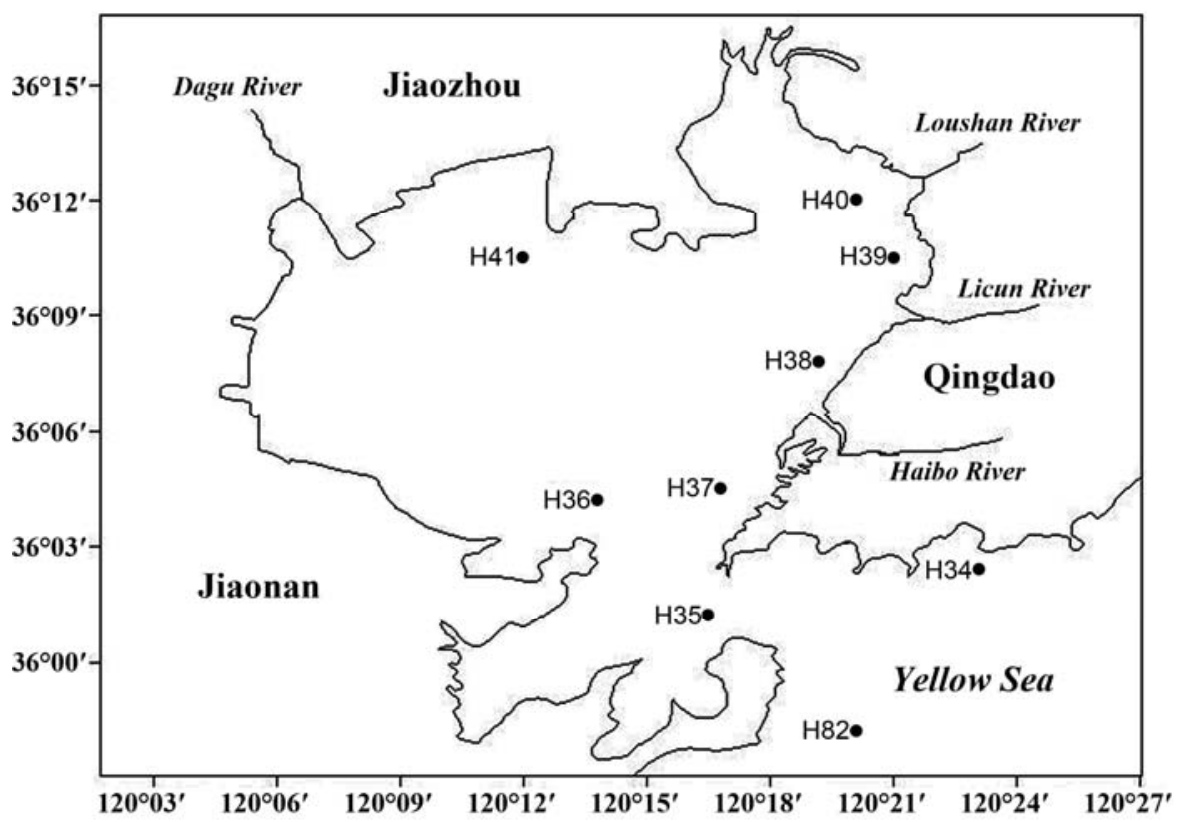

Figure 1. Investigation H-sites in Jiaozhou Bay.

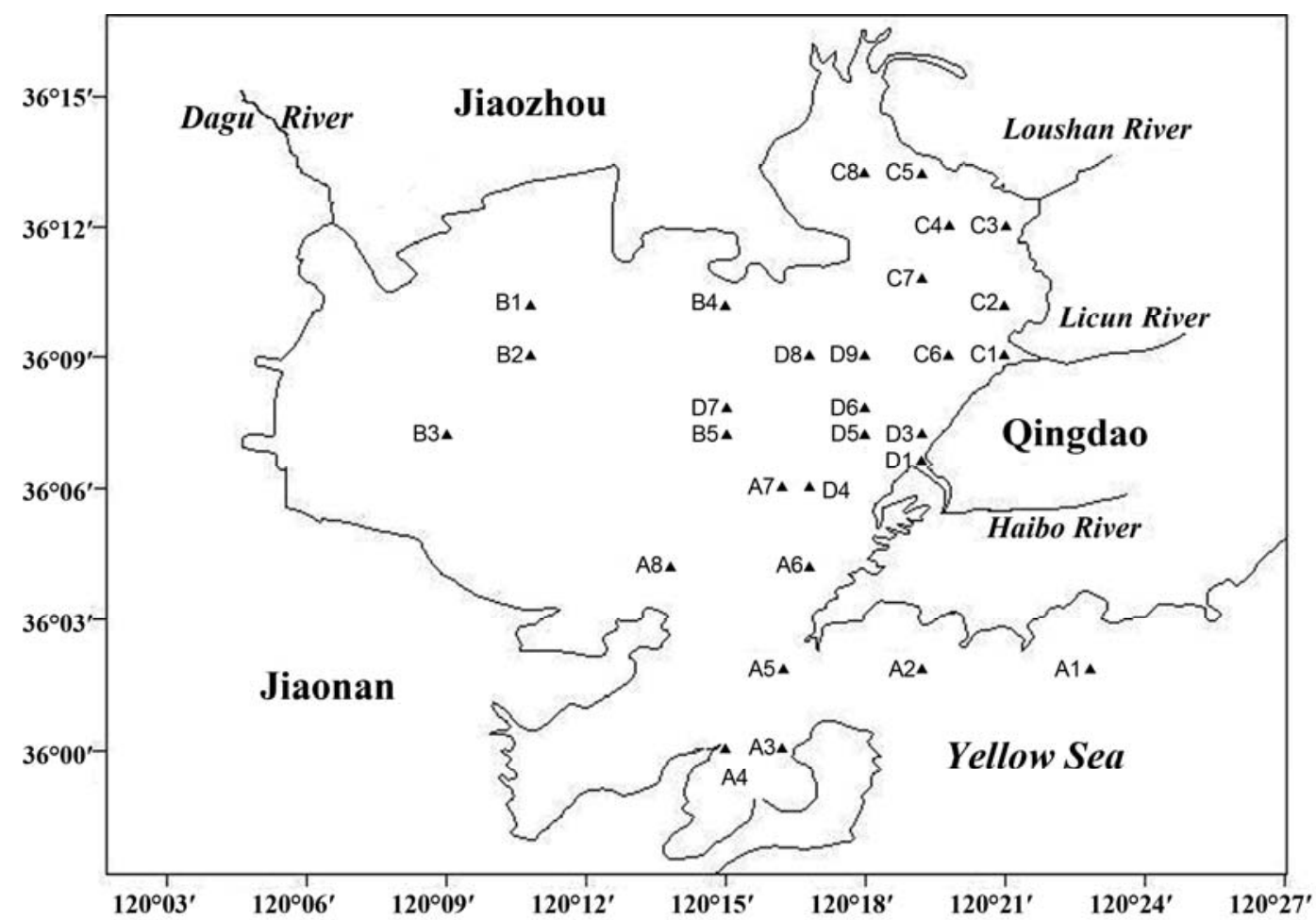

Figure 2. Investigation A-D-sites in Jiaozhou Bay.

surface water in the whole Jiaozhou Bay, $\mathrm{Pb}$ content range was $0.07-2.71 \mu \mathrm{g} / \mathrm{L}$, whose seawater quality was worse than Category I $(1.00 \mu \mathrm{g} / \mathrm{L})$ of the National Standard of China for Seawater Quality GB3097-1997 (in which 4 categories 1 to 4 are classified from the best to the worst), not worse than the Category II $(5.00 \mu \mathrm{g} / \mathrm{L})$.
In June, the $\mathrm{Pb}$ content in Jiaozhou Bay surface water was $0.26-0.88 \mu \mathrm{g} / \mathrm{L}$, the water area reached Category I; in July and September, the $\mathrm{Pb}$ content increased remarkably in surface water, In July, the $\mathrm{Pb}$ content in the surface water is $0.16-2.71 \mu \mathrm{g} / \mathrm{L}$, at stations $\mathrm{H} 82$ and $\mathrm{H} 35$ the $\mathrm{Pb}$ content was $2-2.71 \mu \mathrm{g} / \mathrm{L}$ whose seawater quality 
was worse than Category I. In September, the $\mathrm{Pb}$ content in the surface water was $0.2-1.59 \mu \mathrm{g} / \mathrm{L}$, at stations $\mathrm{H} 82$ and $\mathrm{H} 34$ the $\mathrm{Pb}$ content was $1.16-1.59 \mu \mathrm{g} / \mathrm{L}$ whose seawater quality was worse than Category I. In October, the $\mathrm{Pb}$ content in the surface water was $0.07-0.89 \mu \mathrm{g} / \mathrm{L}$, the whole surface water reached better water quality than Category I (Table 1).

Except for H34, H35 and H82, Pb content in the whole bay qualified the Category I. Moreover, H34, H35, and H82 outside the bay and at the bay mouth showed that in June, July, September, and October, the surface water qualified Category I.

\subsection{Horizontal Distribution}

In June, in the surface water off the shore between estuaries of Haibo River and Lichun River there was a series of semi-concentric circles with the center of H38 where $\mathrm{Pb}$ content was the highest $(0.76 \mu \mathrm{g} / \mathrm{L})$ and decreased generally outwards. In addition, at station H35 in the bay mouth, $\mathrm{Pb}$ content reached $0.88 \mu \mathrm{g} / \mathrm{L}$, higher than those inside the bay, but not higher than standard of Category I $(1.00 \mu \mathrm{g} / \mathrm{L})$. A series of semi-concentric circles with station $\mathrm{H} 35$ as the center in different grades formed and $\mathrm{Pb}$ content of $0.88 \mu \mathrm{g} / \mathrm{L}$ in the center decreased gradually (Figure 3).
In July, an area of high $\mathrm{Pb}$ content at surface appeared in the estuary of Lichun River. The high $\mathrm{Pb}$ content in the center area decreases gradually from $0.88 \mu \mathrm{g} / \mathrm{L}$. Besides, at the bay mouth and outside of it, $\mathrm{Pb}$ content was over $1.00 \mu \mathrm{g} / \mathrm{L}$, which is higher than other stations inside the bay. Therefore, from inner bay to its mouth and further to the area outside of the bay, $\mathrm{Pb}$ content formed a series of grades which increased outwards (Figure 4).

In September, an area of high-content $\mathrm{Pb}$ appeared in the estuary of Haibo River. The peak content in the center at $0.69 \mu \mathrm{g} / \mathrm{L}$ decreased gradually. At the same time, outside the bay, $\mathrm{Pb}$ content was over $1.00 \mu \mathrm{g} / \mathrm{L}$, higher than other stations inside the bay. Therefore, from inside the bay to its mouth and outside the bay, $\mathrm{Pb}$ content formed a series of grades and also increased outwards (Figure 5).

In October, there was no a high-Pb-content area in Jiaozhou Bay at surface water. $\mathrm{Pb}$ content was less than $0.25 \mu \mathrm{g} / \mathrm{L}$. Outside the bay, $\mathrm{Pb}$ content was less than 0.60 $\mu \mathrm{g} / \mathrm{L}$, higher than those of other stations inside it. Therefore, from inside the bay to its mouth and outside, $\mathrm{Pb}$ content formed a series of grades and increased from $0.15 \mu \mathrm{g} / \mathrm{L}$ to $0.60 \mu \mathrm{g} / \mathrm{L}$ (Figure 6).

In June, July, September and October, $\mathrm{Pb}$ content in surface water in the whole Jiaozhou Bay was high in the east and low in the west, high in outer bay and low in inner bay.

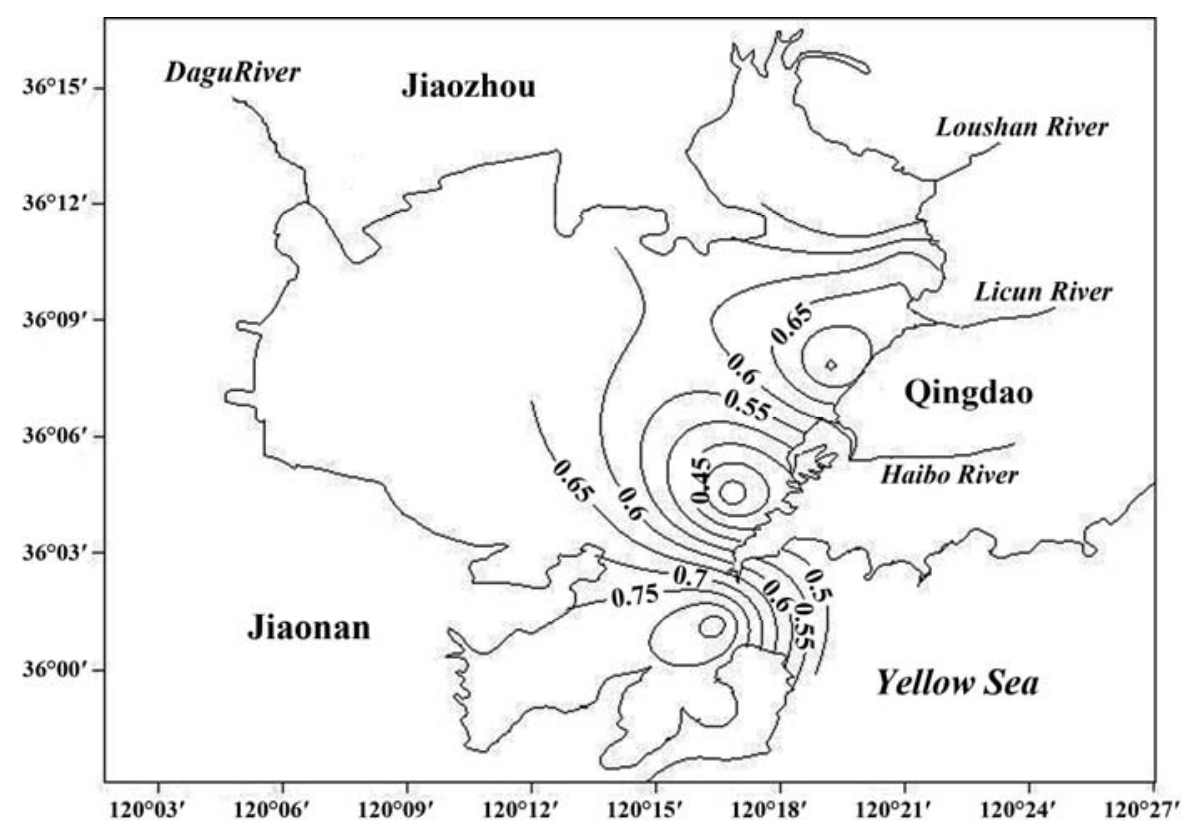

Figure 3. Pb distribution at surface in Jiaozhou Bay in June $(\mu \mathrm{g} / \mathrm{L})$.

Table 1. The surface water quality in Jiaozhou Bay in June, July, September and October.

\begin{tabular}{lllll}
\hline & June & July & September & October \\
\hline $\mathrm{Pb}$ content in seawater $\left(\mu \mathrm{g} \cdot \mathrm{L}^{-1}\right)$ & $0.26-0.88$ & $0.16-2.71$ & $0.2-1.59$ & $0.07-0.89$ \\
The National Standard of China for Seawater Quality & Category I & Category I and II & Category I and II & Category I \\
\hline
\end{tabular}




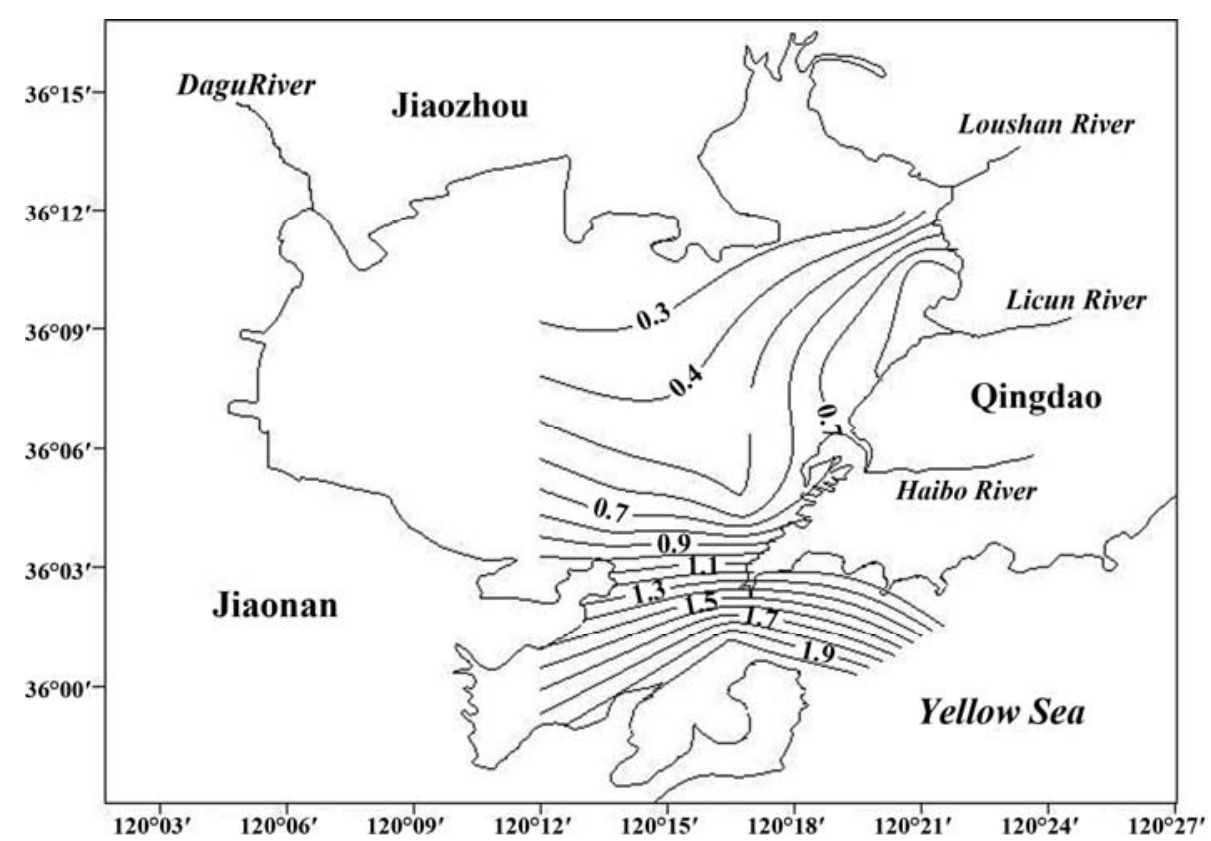

Figure 4. Pb distribution at surface in Jiaozhou Bay in July $(\mu \mathrm{g} / \mathrm{L})$.

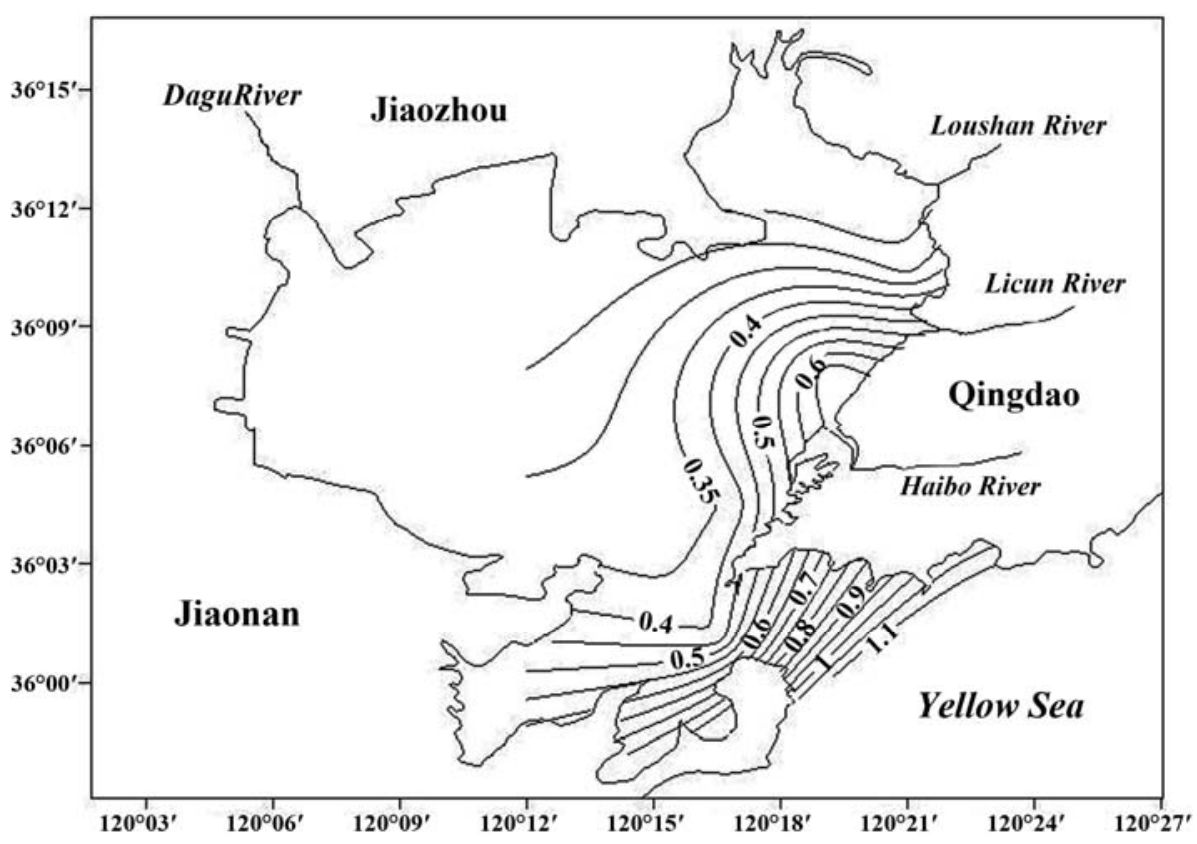

Figure 5. Pb distribution at surface in Jiaozhou Bay in September $(\mu \mathrm{g} / \mathrm{L})$.

In June, July, September and October, $\mathrm{Pb}$ content at bottom in the whole Jiaozhou Bay showed an increasing trend from the inside to the outside (Figures (7)-(10)): $0.17-1.49 \mu \mathrm{g} / \mathrm{L}$ in June, 0.26-0.75 $\mu \mathrm{g} / \mathrm{L}$ in July, 0.15-0.60 $\mu \mathrm{g} / \mathrm{L}$ in September, and 0.07-1.60 $\mu \mathrm{g} / \mathrm{L}$ in October.

\subsection{Vertical Change}

In June, at stations $\mathrm{H} 34, \mathrm{H} 35, \mathrm{H} 36, \mathrm{H} 37, \mathrm{~Pb}$ content at surface was higher than that of the bottom, except for the station H82 outside the bay, being opposite.

In July, at all the stations, $\mathrm{Pb}$ content was higher at surface than at bottom.

In September, all the stations had higher $\mathrm{Pb}$ content at surface than at bottom, except for station H36 at the bay mouth, being opposite.

In October, $\mathrm{Pb}$ content at surface was higher than that at bottom at station H34 only, and was the same at surface 


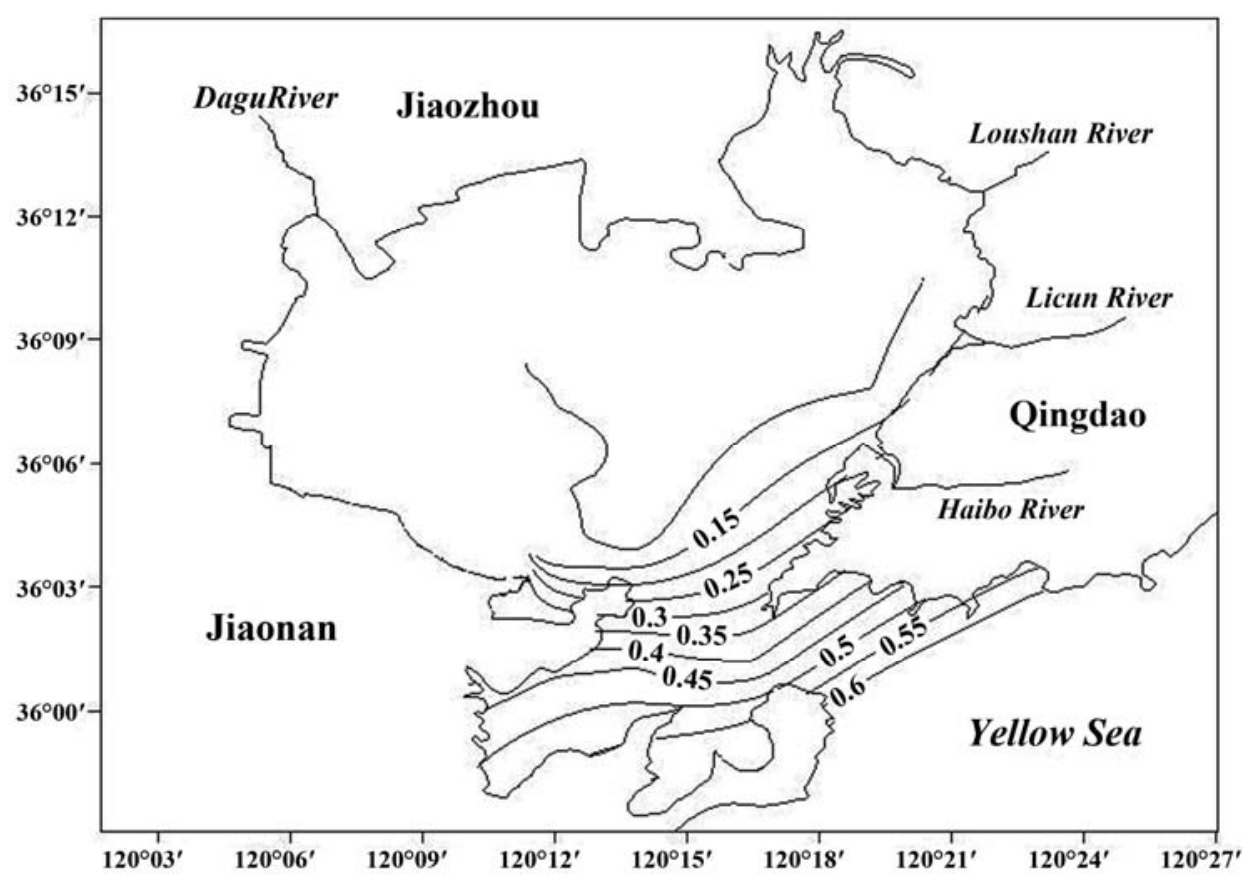

Figure 6. Pb distribution at surface in Jiaozhou Bay in October $(\mu \mathrm{g} / \mathrm{L})$.

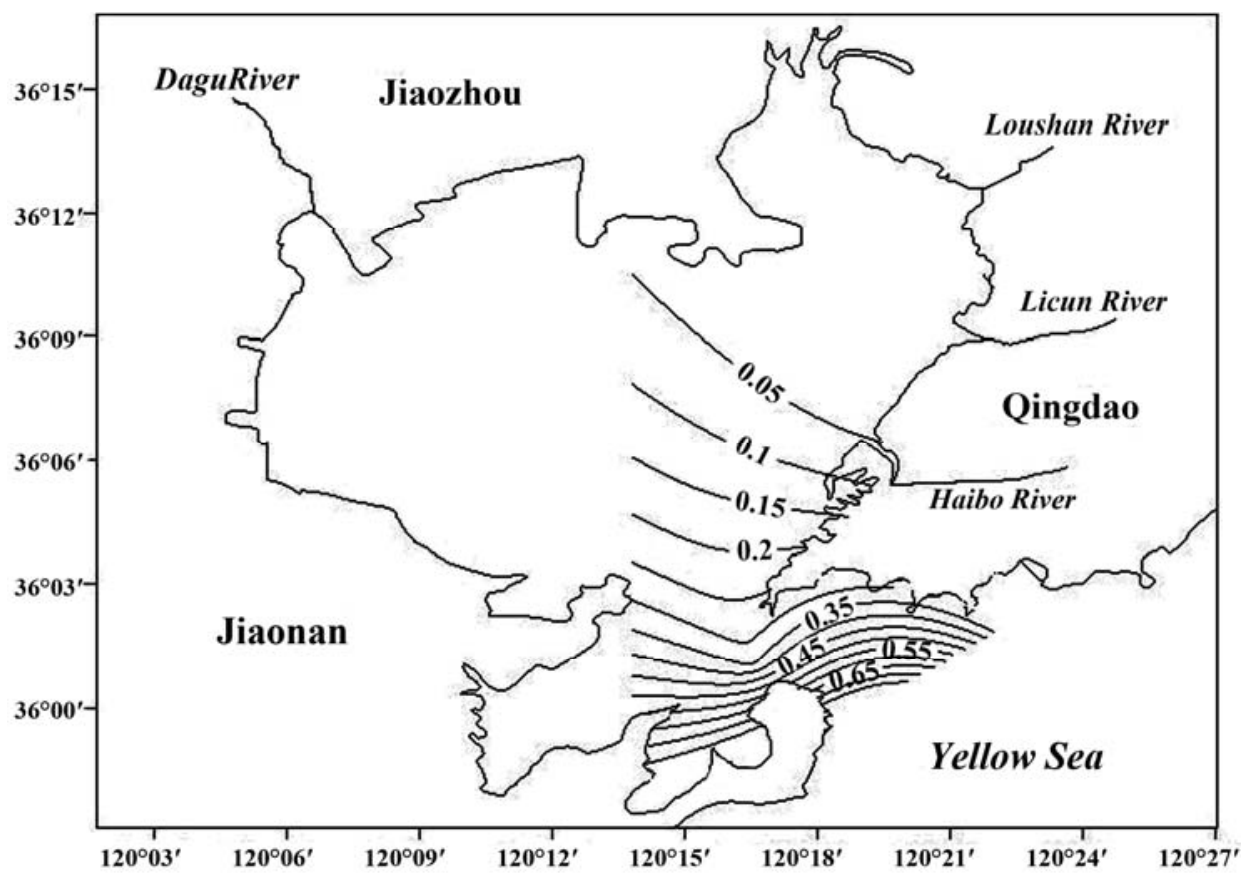

Figure 7. Pb distribution at bottom in Jiaozhou Bay in June $(\mu \mathrm{g} / \mathrm{L})$.

and the bottom at station H35. For the rest stations H36, $\mathrm{H} 37$ and $\mathrm{H} 82, \mathrm{~Pb}$ content was lower at surface and higher at bottom.

Therefore, in June, July and September, $\mathrm{Pb}$ content at almost all the stations at surface was higher than that at bottom, while in October, this trend was opposite, which showed the track of the vertical transfer of $\mathrm{Pb}$.

\subsection{Seasonal Change at Surface}

In monthly variation, $\mathrm{Pb}$ content at surface was low in June in the range of $0.26-0.88 \mu \mathrm{g} / \mathrm{L}$, and obviously increased in July and September for $0.16-2.71 \mu \mathrm{g} / \mathrm{L}$ and 0.2-1.59 $\mu \mathrm{g} / \mathrm{L}$, respectively. In October, it decreased sharply to $0.07-0.89 \mu \mathrm{g} / \mathrm{L}$. Therefore, $\mathrm{Pb}$ content in- 
creased from June to July reaching a peak value, and then fell in September and dropped to a low point in October, which is close to that of in June (Figure 11).

\section{Discussion}

\subsection{Water Quality}

In June, July, September and October, $\mathrm{Pb}$ content at surface inside the bay satisfied the standard of Category I. In July and September, only at its mouth and outside it, $\mathrm{Pb}$ content at surface did not qualify the Category I.
Therefore, there was almost no $\mathrm{Pb}$ pollution inside the Jiaozhou Bay, except for a slight $\mathrm{Pb}$ pollution at its mouth and the outside.

\subsection{Pollution Sources}

The horizontal distribution of $\mathrm{Pb}$ in the bay formed an increasing trend from inside the bay to its mouth and the outside. On the other hand, seawater quality satisfy Category I inside the bay and Category II in the mouth a n

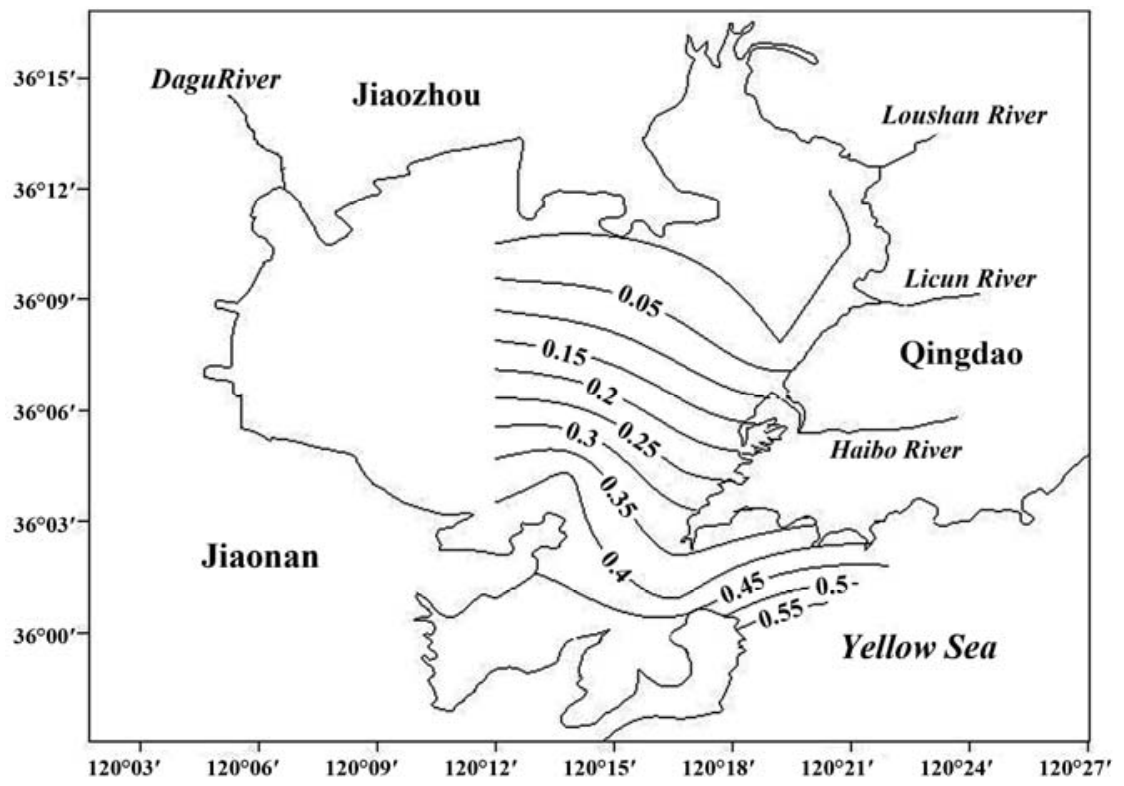

Figure 8. Pb distribution at bottom in Jiaozhou Bay in July $(\mu \mathrm{g} / \mathrm{L})$.

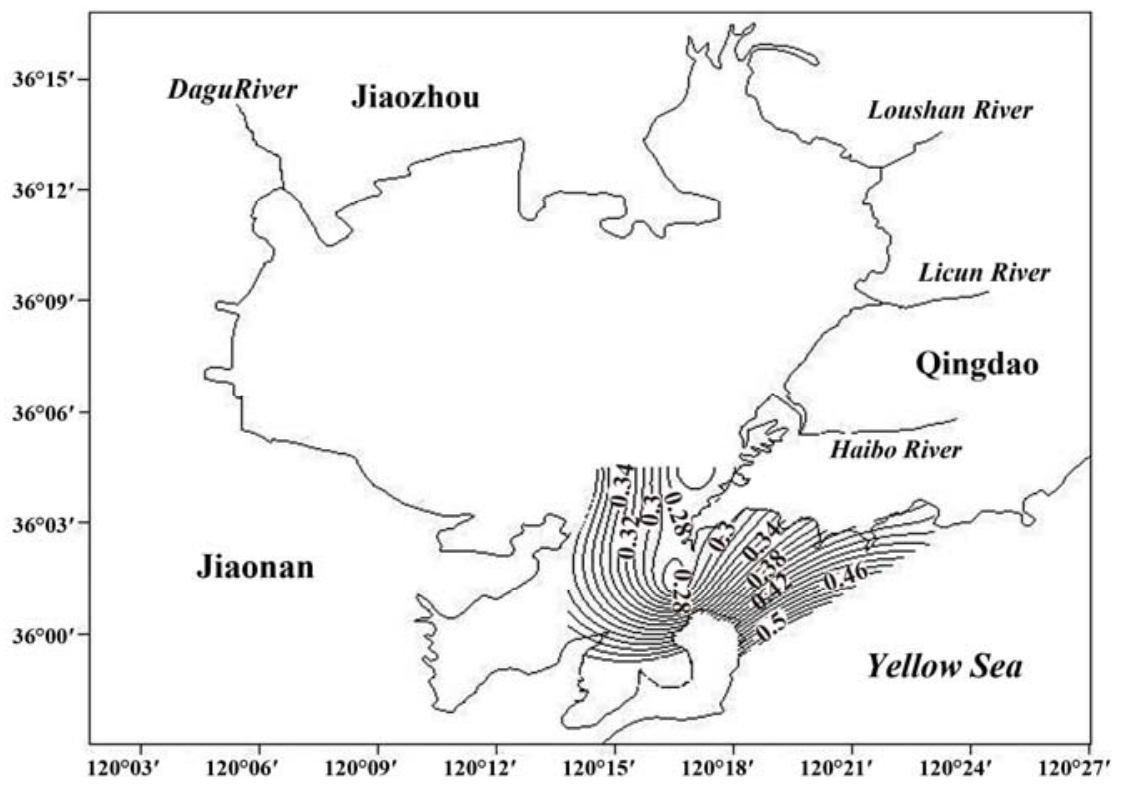


Figure 9. Pb distribution at bottom in Jiaozhou Bay in September $(\mu \mathrm{g} / \mathrm{L})$.

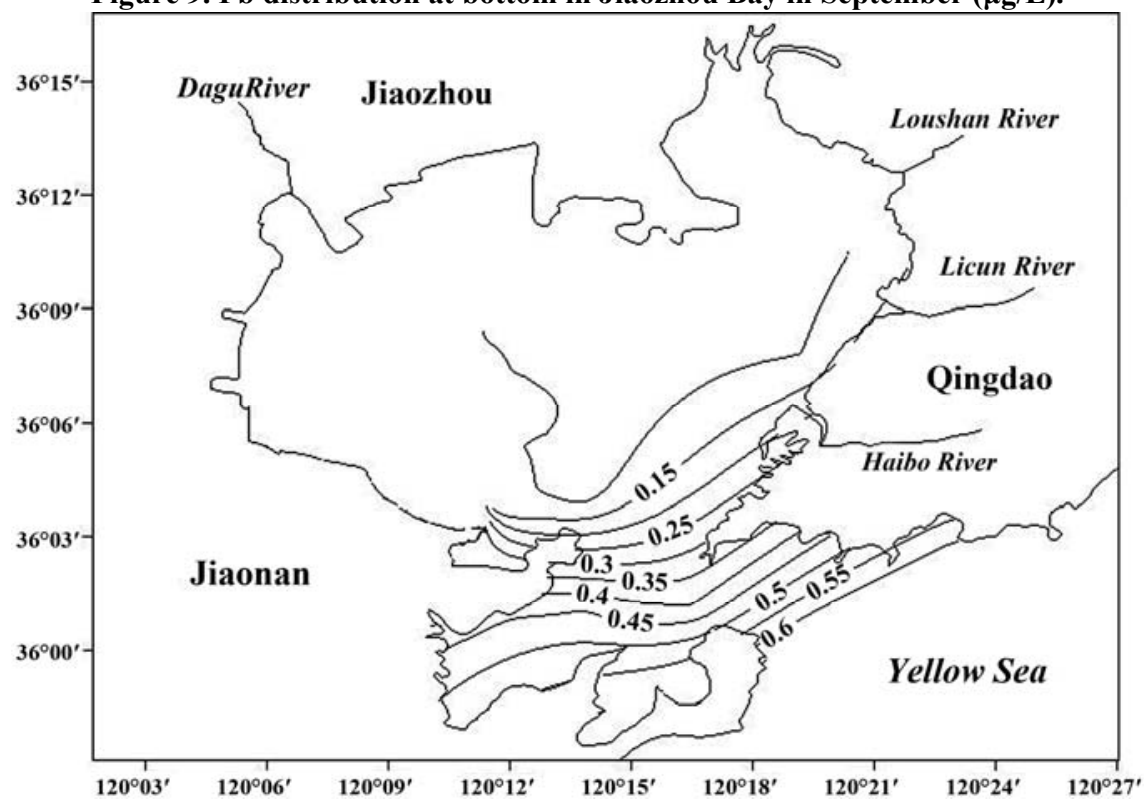

Figure 10. Pb distribution at bottom in Jiaozhou Bay in October $(\mu \mathrm{g} / \mathrm{L})$.

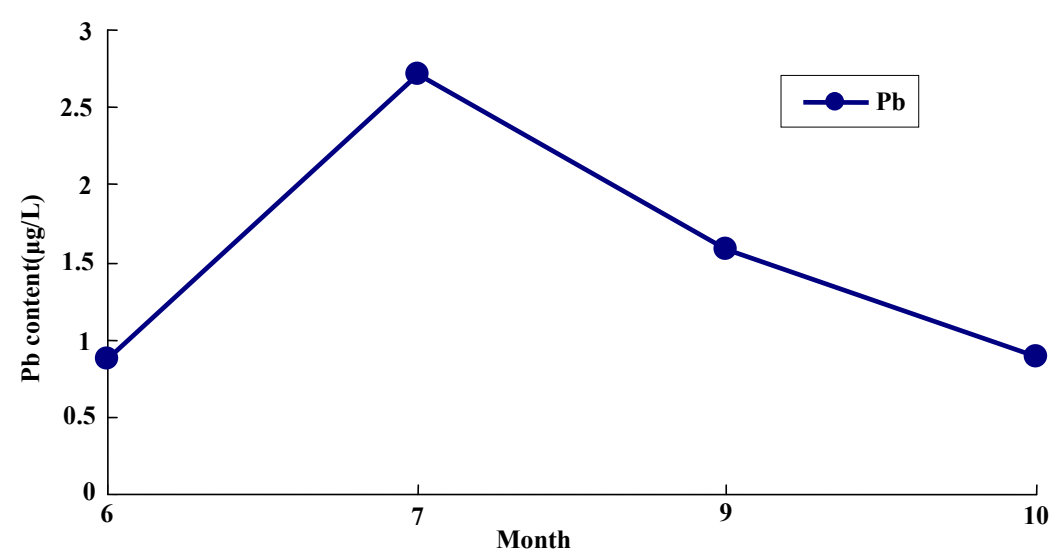

Figure 11. Pb seasonal variation in the surface in Jiaozhou Bay $(\mu \mathrm{g} / \mathrm{L})$.

the outside, indicating that $\mathrm{Pb}$ pollution was from outside the bay. Shown by the vertical distribution of $\mathrm{Pb}$, there was no concentrated pollution source inside, at the mouth, and outside the Jiaozhou Bay, and all the isolines of $\mathrm{Pb}$ paralleled, unveiling that $\mathrm{Pb}$ pollution source was nonpoint. Therefore, $\mathrm{Pb}$ pollution outside the Jiaozhou Bay was originated in the nears-shore of the bay mouth or the open sea nearby, while that of inside the bay, the pollution should be mainly from contributing rivers, and that of the open sea, the pollution was mainly caused from the atmosphere by precipitation.

\subsection{Seasonal Change Process}

In the whole Jiaozhou Bay, $\mathrm{Pb}$ content in June started from a low value, increased gradually, arrived at a peak value in July. Then, it started to decrease in September and fell to the low value in October, close to the value in June. If $\mathrm{Pb}$ pollution was from the water near shore of the bay mouth, by the $\mathrm{Pb}$ seasonal change and horizontal distribution analysis, the authors believed that from the end of raining season and start of next spring, $\mathrm{Pb}$ stayed in land until next rain season in May coming when $\mathrm{Pb}$ was again flushed into the bay [3]. In this way, $\mathrm{Pb}$ at surface in summer was highest in one year; if $\mathrm{Pb}$ was from outside the Bay, the authors believed that it was hardly directively affected by human action because it was far from shore. Generally the $\mathrm{Pb}$ in surface layer of water was positively relevant to input of atmosphere [7]. $\mathrm{Pb}$ was mainly from exhaust of automobiles, and let off first into atmosphere, and then spread over the sea with atmosphere movement. With agglomeration of $\mathrm{Pb}$ parti- 
cles, its diameter increased, and with the action of gravity it fell to the sea waters [8]. So, with the heavy raining season coming, $\mathrm{Pb}$ content in surface water in summer was highest in one year.

\subsection{Transfer Process}

$\mathrm{Pb}$ could be naturally absorbed, complexed, and deposited with particles or organic matter and then transferred from water to sedimentm, which resulted in the decrease in $\mathrm{Pb}$ content in water [3]. In addition, most heavy metals could be absorbed on the surface by organic colloid such as humus to form unstable organic matter. Subsequently, they combined with silicate or oxide of iron and manganese to form stable complexes [9-10]. So, Pb content in water decreased by being depleted with leaving gradually from the source. $\mathrm{Pb}$ transfer process in water was proved by horizontal and vertical distributions at surface and bottom, and seasonal change.

$\mathrm{By} \mathrm{Pb}$ horizontal distributions at surface and bottom in the bay, it was found that $\mathrm{Pb}$ horizontal distributions at surface and bottom has the same trend of change, which unveiled $\mathrm{Pb}$ content decreased gradually and moved downward in water. Therefore, the $\mathrm{Pb}$ content in water kept decreasing.

By vertical distributions at surface and bottom, the transfer process of $\mathrm{Pb}$ is shown.

In July, $\mathrm{Pb}$ at surface was higher than it at bottom; in June and September, $\mathrm{Pb}$ at surface was higher than it at bottom. $\mathrm{Pb}$ at surface was lower than it at bottom except only one station. In July, when $\mathrm{Pb}$ content reached the peak, all the $\mathrm{Pb}$ contents at surface were higher than them at bottom, which indicated that $\mathrm{Pb}$ came into water near shore with rivers or fell into the marine waters at surface from atmosphere or rainfall. In October, when $\mathrm{Pb}$ reached the bottom, almost all the $\mathrm{Pb}$ contents at surface were lower than them at bottom, which indicated that after transfering, $\mathrm{Pb}$ settled to the seafloor into the mud.

By the seasonal change of $\mathrm{Pb}$ in Jiaozhou Bay, the track of $\mathrm{Pb}$ transfering was shown.

In the whole Jiaozhou Bay, Pb content in June started from low value, increased gradually, arrived to the peak in July. Then, it started to decrease in September and fell to the low value in October, close to the value in June. The change of $\mathrm{Pb}$ content above represented that $\mathrm{Pb}$ entered the waterbody through the surface marine waters and left the waterbody through the bottom marine waters, which further proved the process of $\mathrm{Pb}$ transfer.

\section{Conclusions}

In June, July, September and October, in the surface water in the whole Jiaozhou Bay, $\mathrm{Pb}$ content range was
0.07-2.71 $\mu \mathrm{g} / \mathrm{L}$, whose seawater quality was worse than Category I $(1.00 \mu \mathrm{g} / \mathrm{L})$ of the National Standard of China for Seawater Quality GB3097-1997 (in which 4 categories 1 to 4 are classified from the best to the worst), not worse than the Category II $(5.00 \mu \mathrm{g} / \mathrm{L})$. The $\mathrm{Pb}$ content at surface inside the bay satisfied the standard of Category I of sea water quality, and at its mouth and outside it, $\mathrm{Pb}$ content at surface exceeded the Category I. Therefore, there was almost no $\mathrm{Pb}$ pollution inside Jiaozhou Bay. However, the $\mathrm{Pb}$ pollution was slight at its mouth and outside it. If the $\mathrm{Pb}$ pollution in Jiaozhou Bay came from the water near shore of the bay mouth, $\mathrm{Pb}$ went into the waters near shore by the rivers; if the $\mathrm{Pb}$ pollution in Jiaozhou Bay came from the open sea near the mouth outside the bay, $\mathrm{Pb}$ went into the bay mouth outside by deposit of atmosphere and rainfall. The horizontal and vertical distribution at surface and bottom and seasonal change of $\mathrm{Pb}$ in the bay waters proved the process of $\mathrm{Pb}$ transfer: $\mathrm{Pb}$ entered the waterbody through the surface marine waters and left the waterbody through the bottom marine waters, which further proved the process of $\mathrm{Pb}$ transfer. Therefore, the change process of $\mathrm{Pb}$ in Jiaozhou Bay could provide the scientific basis for the control and improvement of the local environment.

\section{References}

[1] K. Meng and T. Z. Sun, "Content Distribution of Heavy Metals in Sediment at East Coast of the Jiaozhou Bay and Differentiation of Pollution Source," Journal of Qufu Normal University, Vol. 22, No. 1, 1996, pp. 77-81.

[2] Y. Cui, B. J. Chen, Y. L. Song and W. L. Wang, "Content of Heavy Metal in Seawater of Jiaozhou Bay and Halobios," Chinese Journal of Applied Ecology, Vol. 8, No. 6, 1997, pp. 650-654. doi:10.1007/s00343-008-0296-9

[3] D. F. Yang, C. Su, Z. H. Gao, P. Y. Sun and L. X. Cao, "Pb Distribution and Translocation in Jiaozhou Bay," Chin Journal Oceanol Limno," Vol. 26, No. 3, 2008, pp. 296- 299.

[4] D. F. Yang, F. Wang, Z. H. Gao, W. L. Cui and S. X. Cui, "Ecological Phenomena of Planktonic Algae in Jiaozhou Bay," Marine Science, Vol. 28, No. 6, 2004, pp. 71-74.

[5] D. F. Yang, Y. Chen, Z. H. Gao, J. Zhang and F. Wang, "Silicon Limitation on Primary Production and Its Destiny in Jiaozhou Bay, China IV Transect Offshore the Coast with Estuaries," Chin Journal Oceanol Limnol, Vol. 23, No. 1, 2005, pp. 72-90.

[6] D. F. Yang, C. Su, Z. H. Gao, P. Y. Sun and L. X. Cao, "Pb Eistribution and Translocation in Jiaozhou Bay," Chinese Journal of Oceanology and Limnology, Vol. 26, No. 3, 2008, pp. 296-299. doi:10.1007/s00343-008-0296-9

[7] F. J. Lin, S. C. Hsu and W. L. Jeng, "Lead in the Southern East China Sea," Marine Environmental Research, Vol. 49, No. 4, 2000, pp. 329-342. 
doi:10.1016/S0141-1136(99)00076-8

[8] Z. P. He, J. X. Song, N. X. Zhang, Y. Y. Xu, G. X. Zheng and P. Zhang, "The Change Characteristics and Effect Factors of Heavy Metals in the Curface Seawater of South Yellowsea," Environmental Science, Vol. 5, No. 5, 2008, pp. 1154-1162.

[9] Z. H. Wang, Q. Lin and C. H. Li, et al., "Change Character and Ecological Evaluation of Heavy Metal in Zhuji- angkou," Journal of Fishery Sciences of China, Vol. 11, No. 3, 2004, pp. 215-219.

[10] J. L. Zheng, Z. D. Wang, Z. Q. Lin, Z. J. Li, Z. H. Zhu and J. S. Chen, "Bayou Chemical Study of Heavy Metal in Zhujiangkou Area--I Chemical Conformation Study of Heavy Metal in Zhujiangkou Area," Oceanologia et Limnologia Sinica, Vol. 13, No. 1, 1982, pp. 19-25. 